\title{
PENGARUH PERPUTARAN KAS DAN PERPUTARAN MODAL KERJA TERHADAP NET PROFIT MARGIN PADA PT.WIJAYAKARYA TBK.
}

\author{
Oleh: \\ Rosnani Siregar, Rizal Ma'ruf Amidy Siregar, Khoiriyah Lubis \\ IAIN PADANGSIDIMPUAN
}

Jalan T. Rizal Nurdin Km. 4.5 Sihitang, Padangsidimpuan

\begin{abstract}
ABSTRAK
Latar belakang masalah dalam penelitian ini adalah adanya fluktuasi dalam perusahaan jika dilihat dari perputaran kas dan perputaran modal kerja yang berdampak terhadap Net Profit Margin. Dan fenomena-fenomena yang terdapat dalam data berbanding terbalik dengan teori. Rumusan masalah penelitian ini adalah apakah perputaran kas berpengaruh secara parsial terhadap Net Profit Margin? Apakah perputaran modal kerja berpengaruh secara parsial terhadap Net Profit Margin? Apakah perputaran kas dan perputaran modal kerja berpengaruh secara simultan terhadap Net Profit Margin? Tujuan penelitian ini adalah untuk mengetahui pengaruh perputaran kas secara parsial terhadap Net Profit Margin, untuk mengetahui pengaruh perputaran modal kerja secara parsial terhadap Net Profit Margin.
\end{abstract}

Pembahasan dalam penelitian berkaitan dengan analisis laporan keuangan Pendekatan yang dilakukan adalah teori-teori yang berkaitan dengan rasio keuangan sebagai aspek atau bagian tertentu dari keilmuan tersebut.

Penelitian ini merupakan penelitian kuantitatif. Sumber data yang digunakan adalah data sekunder yang diambil melalui situs www.idx.co.id dari tahun 2008-2017 per triwulan dengan 39 sampel. Alat analisis yang digunakan adalah uji normalitas, uji linieritas, uji autokorelasi, uji heterokedastisitas, analisis regresi berganda dan uji hipotesis dengan bantuan SPSS Versi 22.00.

Hasil penelitian menunjukkan secara parsial (uji t) Perputaran Kas tidak berpengaruh signifikan terhadap Net Profit Margin dengan nilai thitung < ttabel $(0,943<2,02809)$ dan nilai signifikansi < 0,05 (0,625 > 0,05. Sementara Perputaran Modal kerja berpengaruh signifikan terhadap Net Profit Margin dengan nilai thitung $>$ ttabel $(2,428>2,02809)$ dan nilai signifikansi <0,005 (0,020 < 0,05). Hasil penelitian secara simultan (uji f) menyatakan bahwa, Perputaran Kas dan Perputaran Modal Kerja berpengaruh signifikan terhadap Net Profit Margin dengan nilai Fhitung $>$ Ftabel $(3,923>3,26)$ dan nilai signifikansi <0,05 (0,029 < 0,05). Hasil dari koefisien determinasi Adjusted $R$ Square sebesar 0,136 hal ini berarti pengaruh Perputaran Kas dan Perputaran Modal Kerja terhadap Net Profit Margin sebesar 13,6\% sedangkan sisanya sebesar $86,4 \%$ dipengaruhi oleh variabel lain yang tidak dimasukkan dalam model ini.

Kata Kunci: Perputaran Kas, Perputaran Modal Kerja dan Net Profit Margin 


\section{PENDAHULUAN}

Dunia usaha yang semakin ketat dan tingginya persaingan sehingga perlu meningkatkan efesiensi dan efektifitas untuk menjaga eksistensi perubahan dimasa sekarang dan masa yang akan datang untuk itu suatu perusahaan harus mengetahui kondisi dari suatu perusahaan, salah satunya dengan menganalisis laporan keuangan. Kondisi perusahaan yang baik akan menjadi kekuatan perusahaan untuk dapat bertahan dan berkembang mencapai tujuan perusahaan. ${ }^{1}$ Manajemen perusahaan dalam prakteknya dituntut harus mampu untuk memenuhi target yang ditetapkan, artinya besarnya keuntungan haruslah dicapai dengan yang diharapkan dan bukan berarti asal untung. ${ }^{2}$

Naik turunya rasio profitabilitas (Net Profit Margin) bisa disebabkan karena beberapa faktor. Diantaranya faktor tersebut adalah perputaran kas dan perputaran modal kerja. Hakikatnya perusahaan tidak akan berjalan apabila tidak adanya kas dan modal kerja untuk menjalankan perusahaan tersebut. Itulah mengapa kas dan modal kerja memiliki peran vital dalam perusahaan.3

Perputaran kas berfungsi untuk mengukur tingkat kecukupan modal kerja perusahaan yang dibutuhkan untuk membayar tagihan dan membiayai penjualan. Artinya perputaran kas digunakan untuk mengukur tingkat ketersediaan kas untuk membayar tagihan (utang) dan biaya-biaya yang berkaitan dengan penjualan.

Kas merupakan aktiva yang paling likuid atau merupakan salah satu unsur modal yang paling tinggi likuiditasnya, berarti bahwa semakin besar jumlah kas yang dimiliki oleh perusahaan akan semakin tinggi pula tingkat likuiditasnya. Akan tetapi, suatu perusahaan yang mempunyai tingkat likuiditas yang tinggi karena adanya kas dalam jumlah yang besar yang berarti tingkat perputaran kas tersebut rendah dan mencerminkan adanya over investment dan berarti pula perusahaan kurang efektif dalam mengelola kas. Jumlah kas yang relatif kecil akan diperoleh tingkat perputaran kas yang tinggi dan keuntungan yang diperoleh akan lebih besar. 4

\footnotetext{
${ }^{1}$ Ali Mahmuda, Sistem Informasi Akuntansi Perusahaan, (Jakarta: PT. Grasindo Anggota Ikapo, 2005), hlm.307.

${ }^{2}$ Kasmir, Analisis Laporan Keuangan, (Jakarta: PT. Raja Garavindo Persada, 2012), hlm. 196.

${ }^{3}$ OliviaMadaRolos,http://reforsitory.usu.ac.id/bitstream/12345678/22388/5/chapter\%201.pdf, diakses pada 16 februari 2018, pukul 12.20 wib.

${ }^{4}$ Kasmir, Op. Cit., hlm.132-140.
} 
Perputaran modal kerja (Working Capital Over) merupakan salah satu rasio untuk mengukur atau menilai keefektifan modal kerja perusahaan selama periode tertentu. Perputaran modal kerja yang tinggi diakibatkan rendahnya modal kerja yang ditanam dalam persediaan dan piutang. Semakin tinggi perputaran modal kerja semakin efektif penggunaan modal kerja perusahaan, sebaliknya semakin rendah perputaran modal kerja semakin tidak efektif penggunaan modal kerja perusahaan sehingga terhambatnya kegiatan operasional perusahaan yang akhirnya menghambat kemampuan perusahaan dalam memperoleh keuntungan. 5

Untuk lebih memfokuskan kajian penelitian, maka disajikan data laporan keuangan PT. Wijaya Karya sebagai sumber informasi yang kemudian akan menjadi dasar analisis data dalam penelitian ini:

Tabel I.1

\section{Data Penjualan, Rata-rata Kas, Rata-rata Modal Kerja dan Laba Bersih pada PT. Wijaya Karya Tbk ( dalam Ribuan Rupiah)}

\begin{tabular}{|l|l|l|l|l|}
\hline Tahun & Penjualan & $\begin{array}{l}\text { Rata-rata } \\
\text { Kas }\end{array}$ & $\begin{array}{l}\text { Rata-rata } \\
\text { Modal Kerja }\end{array}$ & $\begin{array}{l}\text { Laba } \\
\text { Bersih }\end{array}$ \\
\hline 2008 & 6.559 .077 .280 & 1.051 .432 .167 & 1.384 .641 .206 & 156.034 .395 \\
\hline 2009 & 6.590 .857 .284 & 1.210 .888 .160 & 1.532 .941 .234 & 189.222 .076 \\
\hline 2010 & 6.022 .921 .894 & 1.227 .704 .869 & 1.801 .623 .781 & 284.922 .192 \\
\hline 2011 & 7.741 .827 .272 & 1.244 .316 .237 & 2.219 .375 .875 & 401.827 .929 \\
\hline 2012 & 9.816 .085 .895 & 1.499 .142 .819 & 2.814 .005 .594 & 508.763 .662 \\
\hline 2013 & 11.884 .667 .552 & 1.386 .707 .038 & 3.226 .958 .875 & 624.371 .679 \\
\hline 2014 & 12.463 .216 .288 & 2.300 .892 .182 & 4.978 .758 .224 & 750.795 .820 \\
\hline 2015 & 13.620 .101 .419 & 2.560 .120 .483 & 5.438 .101 .365 & 703.005 .054 \\
\hline 2016 & 15.668 .832 .513 & 9.269 .999 .584 & 12.498 .715 .304 & 1.147 .144 .922 \\
\hline 2017 & 26.176 .403 .026 & 11.253 .778 .215 & 14.631 .824 .613 & 1.356 .115 .489 \\
\hline
\end{tabular}

Sumber: Laporan Keuangan PT.Wijaya Karya Tbk

5Jumingan, Analisis Laporan Keuangan , (Jakarta: PT. Bumi Aksara, 2014), hlm.66-67. 
PENGARUH... Rosnani

Tabel I.2

\section{Data Perputaran Kas, Perputaran Modal Kerja dan Net Profit Margin pada PT.Wijaya karya}

\begin{tabular}{|c|c|c|c|}
\hline Tahun & $\begin{array}{c}\text { Perputaran } \\
\text { Kas } \\
\text { (kali) }\end{array}$ & $\begin{array}{c}\text { Perputaran } \\
\text { Modal Kerja } \\
\text { (kali) }\end{array}$ & $\begin{array}{c}\text { Net Profit } \\
\text { Margin } \\
\text { (\%) }\end{array}$ \\
\hline 2008 & 6,24 & 4,74 & 0,03 \\
\hline 2009 & 5,44 & 4,29 & 0,03 \\
\hline 2010 & 4,91 & 3,34 & 0,05 \\
\hline 2011 & 6,22 & 3,49 & 0,05 \\
\hline 2012 & 6,55 & 3,49 & 0,05 \\
\hline 2013 & 8,57 & 3,68 & 0,05 \\
\hline 2014 & 5,42 & 2,50 & 0,06 \\
\hline 2015 & 5,32 & 2,50 & 0,05 \\
\hline 2016 & 1,69 & 1,25 & 0,07 \\
\hline 2017 & 2,33 & 1,79 & 0,05 \\
\hline
\end{tabular}

Sumber: Laporan Keuangan PT.Wijaya Karya Tbk data diolah

Pada tabel 1.2 menunjukkan tentang perputaran kas, perputaran modal kerja dan Net Profit Margin pada PT.Wijaya Karya dapat dilihat tahun 2009 perputaran kas mengalami penurunan dari tahun 2008, sedangkan Net Profit Margin mengalami peningkatan. Pada tahun 2010 perputaran kas mengalami penurunan dari tahun 2009, sedangkan Net Profit Margin mengalami peningkatan. Pada tahun 2011 perputaran kas mengalami peningkatan dari tahun 2010, sedangkan Net Profit Margin mengalami penurunan. Pada tahun 2012 perputaran kas mengalami peningkatan dari tahun 2011, sedangkan Net Profit Margin tetap. Pada tahun 2013 perputaran kas mengalami peningkatan dari tahun 2012, sedangkan Net Profit Margin mengalami peningkatan. Pada tahun 2014 perputaran kas mengalami penurunan dari tahun 2013, sedangkan Net Profit Margin mengalami peningkatan. Pada tahun 2015 perputaran kas mengalami penurunan dari tahun 2014, sedangkan Net Profit Margin mengalami penurunan. Pada tahun 2016 perputaran kas mengalami penurunan dari tahun 2015, sedangkan Net Profit Margin mengalami 
peningkatan. Pada tahun 2017 perputaran kas mengalami peningkatan dari tahun 2016, sedangkan Net Profit Margin mengalami penurunan.

Dari tabel 1.2 PT.Wijaya Karya dapat juga dilihat pada tahun 2009 perputaran modal kerja mengalami penurunan dari tahun 2008, sedangkan Net Profit Margin mengalami peningkatan. Pada tahun 2010 perputaran modal kerja mengalami penurunan dari tahun 2009, sedanngkan Net Profit Margin mengalami peningkatan. Pada tahun 2011 perputaran modal kerja mengalami peningkatan dari tahun 2010, sedangkan Net Profit Margin mengalami penurunan. Pada tahun 2012 perputaran modal kerja tetap dari tahun 2011, sedangkan Net Profit Margin tetap. Pada tahun 2013 perputaran modal kerja mengalami peningkatan dari tahun 2012, sedangkan Net Profit Margin mengalami peningkatan. Pada tahun 2014 perputaran modal kerja mengalami peningkatan dari tahun 2013, sedangkan Net Profit Margin mengalami peningkatan. Pada tahun 2015 perputaran modal kerja mengalami peningkatan dari tahun 2014, sedangkan Net Profit Margin mengalami penurunan. Pada tahun 2016 perputaran modal kerja mengalami penurunan dari tahun 2015, sedangkan Net Profit Margin mengalami peningkatan. Pada tahun 2017 perputaran modal kerja mengalami peningkatan dari tahun 2016, sedangkan Net Profit Margin mengalami peningkatan.

Berdasarkan uraian dan permasalahan diatas maka peneliti tertarik untuk melakukan penilitian tentang perputaran kas, perputaran modal kerja dan Net Profit Margin. Penelitian yang dilakukan dirangkum dalam judul penelitian "Pengaruh Perputaran Kas dan Perputaran Modal Kerja terhadap Net Profit Margin pada PT.Wijaya Karya Tbk."

\section{LANDASAN TEORI}

\section{Analisis Rasio}

Analisis rasio merupakan salah satu alat analisis keuangan yang paling popular dan banyak digunakan. Meskipun perhitungan rasio hanyalah merupakan operasi aritmatika sederhana, namun hasilnya memerlukan interpretasi yang tidak mudah. Agar hasil perhitungan rasio menjadi bermakna, sebuah rasio sebaiknya mengacu pada hubungan ekonomis yang penting. Rasio harus diinterpretasikan dengan hatihati karena faktor-faktor yang mempengaruhi pembilang dapat berkorelasi dengan hati-hati karena faktor-faktor yang mempengaruhi penyebut. ${ }^{6}$ Menurut John J. Wild

\footnotetext{
${ }^{6}$ Heri, Analisis Laporan Keuangan, (Jakarta: PT. Bumi Aksara, 2014), hlm.22.
} 
analisis rasio merupakan suatu alat untuk menyediakan pandangan terhadap kondisi yang mendasari dalam penilaian kinerja keuangan. Rasio merupakan salah satu titik awal, bukan titik akhir dari penyajian laporan keuangan. Rasio yang diinterpretasikan dengan tepat mengidentifikasi area yang memerlukan investigasi lebih lanjut. Analisis rasio dapat mengungkapkan hubungan penting dan menjadi dasar perbandingan dalam menemukan kondisi dan tren yang sulit untuk dideteksi dengan mempelajari masing-masing komponen yang membentuk rasio. ${ }^{7}$

\section{Analisis Rasio Keuangan}

Rasio keuangan terbentuk dari unsur-unsur laporan keuangan untuk menginterpretasikan atau memahami kondisi keuangan perusahaan pada suatu periode tertentu. Rasio keuangan dapat menunjukkan gambaran tentang posisi keuangan perusahaan periode sebelumnya atau dengan perusahaan sejenis yang lainnya. Rasio menggambarkan suatu hubungan perimbangan antara suatu jumlah pos tertentu dan jumlah pos yang lain. Analisis rasio keuangan juga merupakan metode analisis yang sering dipakai karena merupakan metode yang sederhana dan menghilangkan faktor bias dari nilai absolute dalam pemaknaan atas suatu kondisi keuangan. ${ }^{8}$

\section{Pengertian Net Profit Margin}

Margin laba bersih merupakan ukuran keuntungan dengan membandingkan antara laba bersih dibandingkan dengan penjualan. Rasio ini menunjukkan pendapatan bersih perusahaan atas penjualan

Rasio ini mengukur efektifitas secara keseluruhan yang ditujukan oleh besar kecilnya tingkat keuntungan yang diperoleh dalam hubungannya dengan penjualan maupun investasi.Semakin baik rasio profitabilitas maka semakin baik menggambarkan kemampuan tingginya perolehan keuntungan perusahaan. 9

\section{Pengertian Kas}

${ }^{7}$ John J. Wild dkk, Analisis Laporan Keuangan, edisi 8: Buku I, Diterjemahkan dari “ Financial Statement Analysis, 8 ed "oleh Yanivi S. Bachtiar dan S. Nurwahyu, (Jakarta: Salemba Empat, 2005), hlm. 36.

${ }^{8}$ Slamet Haryono, Analisis Keuangan, (Medan: USU Press, 2013), hlm.92.

${ }^{9}$ Irham fahmi, Analisis Kinerja Keuangan (Bandung: Alfabeta, 2012), hlm. 68. 
Kas merupakan suatu alat pertukaran dan juga digunakan sebagai ukuran dalam akuntansi. Dalam neraca, kas merupakan aktiva yang paling lancar, dalam arti paling sering berubah.Hampir pada setiap transaksi dengan pihak luar selalu mempengaruhi kas.

Kas adalah aktiva yang tidak produktif, oleh karena itu harus dijaga supaya jumlah kas tidak terlalu besar sehingga tidak ada “idle cash". Daya beli uang bisa berubah- ubah mungkin naik atau turun tetapi kenaikan atau penurunan daya beli ini tidak akan mengakibatkan penilaian kembali terhadap kas. ${ }^{10}$

\section{Pengertian Modal Kerja}

Suatu analisa terhadap sumber dan penggunaan modal kerja sangat penting bagi penganalisa intern maupun ekstern, disamping masalah modal kerja erat hubungannya dengan operasi perusahaan sehari- hari juga menunjukkan tingkat keamanan atau margin of safety para kreditur terutama kreditur jangka pendek.Adanya modal kerja yang cukup sangat penting bagi perusahaan karena dengan modal kerja yang cukup itu memungkinkan bagi perusahaan untuk beroperasi dengan seekonomis mungkin dan perusahaan tidak mengalami kesulitan atau menghadapi bahaya- bahaya yang mungkin timbul karena adanya krisis atau kekacauan keuangan.

\section{METODOLOGI PENELITIAN}

Penelitian ini dilakukan di PT.Wijaya Karya Tbk yang beralamat di JL. D.I Panjaitan kav. 9-10, Jakarta 13340 Indonesia. Penelitian ini dilakukan mulai Februari 2018 sampai dengan November 2018. Didalam penelitian ini data yang diambil bersumber dari situs resmi perusahaan dan juga dari data yang dicantumkan oleh Bursa Efek Indonesia dan Daftar Efek Syariah melalui situs resmi di $w w w . i d x . c o . i d$.

Penelitian ini dilakukan dengan metode kuantitatif. Penelitian kuantitatif adalah penelitian yang bekerja dengan angka, yang angkanya berwujud bilangan yang dianalisis menggunakan statistik untuk menjawab pertanyaan atau hipotesis penelitian yang sifatnya spesifik dan untuk melakukan prediksi suatu variabel yang

${ }^{10}$ Zaki Baridwan, Intermediate Accounting (Yogyakarta:PFE- Yogyakarta,2004), hlm.83. 
lain. ${ }^{11}$ Dalam penelitian ini terdapat tiga variabel yaitu Perputaran $\operatorname{Kas}\left(\mathrm{X}_{1}\right)$, Perputaran Modal Kerja (X2) sebagai variabel bebas dan Net Profit Margin (Y) sebagai variabel terikat.

\section{HASIL PENELITIAN}

\section{Pengaruh Perputaran Kas terhadap Net Profit Margin}

Teori yang dikemukakan James O. Gill, rasio perputaran kas (cash turn over) berfungsi untuk mengukur tingkat kecukupan modal kerja perusahaan yang dibutuhkan untuk membayar tagihan dan membiayai penjualan. Artinya rasio ini digunakan untuk mengukur tingkat ketersediaan kas untuk membayar tagihan (utang) dan biaya- biaya yang berkaitan dengan penjualan.

Berdasarkan hasil uji t menunjukkan variabel Perputaran Kas memiliki nilai thitung < ttabel $(0,943<2,02809)$ artinya $\mathrm{Ha1}_{\mathrm{a}}$ ditolak dan $\mathrm{H}_{01}$ diterima, jadi dapat disimpulkan bahwa Perputaran Kas tidak berpengaruh secara parsial terhadap Net Profit Margin.

Hasil penelitian ini sejalan dengan hasil penelitian yang dilakukan oleh Lisnawati Dewi, yang dalam penelitiannya menunjukkan bahwa Perputaran Kas secara parsial tidak berpengaruh signifikan terhadap Net Profit Margin.

\section{Pengaruh Perputaran Modal Kerja terhadap Net Profit Margin}

Perputaran modal kerja atau working capital turn over merupakan salah satu rasio untuk mengukur atau menilai keefektifan modal kerja perusahaan selama periode tertentu. Artinya seberapa banyak modal kerja berputar selama suatu periode atau dalam suatu periode. Untuk mengukur rasio ini, kita membandingkan antara penjualan dengan modal kerja atau dengan modal kerja rata- rata.Dari hasil penilaian, apabila perputaran modal kerja yang rendah, dapat diartikan perusahaan sedang kelebihan modal kerja.Hal ini mungkin disebabkan karena rendahnya perputaran persediaan atau piutang atau saldo kas yang terlalu besar. Demikian pula sebaliknya jika perputaran modal kerja tinggi, mungkin disebabkan tingginya perputaran persediaan atau perputaran piutang atau saldo kas yang terlalu kecil.

\footnotetext{
${ }^{11}$ Asmadi Alsa, Pendekatan Kuantitatif dan Kualitatif serta Kombinasinya dalam Penelitian Psikologi (Yogyakarta: Pustaka Pelajaran, 2004), hlm.13.
} 
Berdasarkan hasil uji t menunjukkan variabel Perputaran Modal Kerja memiliki nilai thitung $>$ ttabel $(2,428>2,02809)$ dan nilai signifikansi $<0,005(0,020<0,05)$ artinya $\mathrm{H}_{01}$ ditolak dan $\mathrm{H}_{\mathrm{a}}$ diterima, jadi dapat disimpulkan bahwa Perputaran Modal Kerja secara parsial berpengaruh dan signifikan terhadap Net Profiit Margin.

Hasil penelitian ini sejalan dengan hasil penelitian yang dilakukan oleh Dewi Noratika, yang didalam penelitiannya menunjukkan bahwa Perputaran Modal Kerja secara parsial berpengaruh signifikan terhadap Net Profit Margin.

Penelitian yang dilakukan oleh Subowo, yang penelitiannya menunjukkan bahwa Perputaran Modal Kerja secara parsial berpengaruh signifikan terhadap Laba (NPM).

\section{Pengaruh Perputaran Kas dan Perputaran Modal Kerja secara simultan terhadap Net Profit Margin}

Berdasarkan hasil uji F diperoleh nilai Fhitung $>$ Ftabel $(3,923>3,26)$ dan nilai signifikansi <0,05 $(0,029<0,05)$ artinya $\mathrm{H}_{33}$ diterima dan $\mathrm{H}_{03}$ ditolak, jadi dapat disimpulkan bahwa Perputaran Kas dan Perputaran Modal Kerja secara simultan berpengaruh terhadap Net Profit Margin.

Menurut Dewi Noratika menyatakan bahwa secara simultan dan parsial Perputaran Kas dan Perputaran Modal Kerja berpengaruh positif dan signifikan terhadap Net Profit Margin

Hasil penelitian ini sejalan dengan hasil penelitian yang dilakukan oleh Subowo, yang di dalam penelitiannya menunjukkan bahwa secara simultan variabel Pertumbuhan penjualan, pertumbuhan kas, perputaran piutang, perputaran persediaan perputaran modal kerja berpengaruh signifikan terhadap laba usaha (NPM).

Tingkat pengaruh Perputaran Kas dan Peputaran Modal Kerja dapat dilihat dari hasil Adjusted R Square. Beasarnya Adjusment $R$ Square sebesar 0,136 artinya persentase sumbangan pengaruh variabel independen yaitu Perputaran Kas, Perputaran Modal Kerja dan Net Profit Margin sebesar 13,6 \% sedangkan sisanya 86,4 $\%$ dipengaruhi oleh variabel lain yang tidak dimasukkan didalam model ini. 


\section{DAFTAR PUSTAKA}

Ali Mahmuda, Sistem Informasi Akuntansi Perusahaan Jakarta: PT. Grasindo Anggota Ikapo, 2005.

Andi Buchari \& Rivai Veithzal, mengislamkan Ekonomi Masyarakat \& Memasyarakatkan Ekonomi Islam Jakarta: Bumi Aksara, 2009.

Asmadi Alsa, Pendekatan Kuantitatif dan Kualitatif serta Kombinasinya dalam Penelitian Psikologi, Yogyakarta: Pustaka Pelajaran, 2004.

Duwi Priyatno, SPSS22 Pengolah Data Terpraktis, Yogyakarta: Andi Yogyakarta, 2014.

Heri, Analisis Laporan Keuangan, Jakarta: PT. Bumi Aksara, 2014.

Irham fahmi, Analisis Kinerja Keuangan Bandung: Alfabeta, 2012.

John J. Wild dkk, Analisis Laporan Keuangan, edisi 8: Buku I, Diterjemahkan dari

“Financial Statement Analysis, 8 ed "oleh Yanivi S. Bachtiar dan S. Nurwahyu, Jakarta: Salemba Empat, 2005.

Jumingan, Analisis Laporan Keuangan Jakarta: PT. Bumi Aksara, 2014.

Kasmir, Analisis Laporan Keuangan Jakarta: PT. Raja Garavindo Persada, 2012.

Munawir, Analisa Laporan Keuangan ,Yogyakarta:Liberty,2007.

Muhammad Teguh, Metodologi Penelitian Ekonomi Teori dan Aplikasi Jakarta: PT RajaGrafindo Persada, 2005.

Mudrajad Kuncoro, Metode Riset untuk Bisnis \& Ekonomi: Bgaimana Meneliti \& Menulis Tesis?, Jakarta: Erlangga, 2009.

Nur Asmawi dan Masyhuri, Metodologi Riset Manajemen Pemasaran, Malang: UIN Maliki Press, 2011.

Nugroho Budiyuwono, Pengantar Statistik Ekonomi dan - rusahaan Yogyakarta:UPP AMP YKPN,1993. 
Syahnan, Manajemen Keuangan, Medan: USU Press,2013.

Slamet Haryono, Analisis Keuangan, Medan: USU Press, 2013.

Syahatah Husein, Pokok-pokok Pikiran Akuntansi Islam, Jakarta: Akbar Media Eka Sarana,2001.

Sugiyono, Metode Penelitian Bisnis, Bandung: Alfabeta, 2012.

Zaki Baridwan, Intermediate Accounting Yogyakarta:PFE- Yogyakarta, 2004.

\section{Sumber Lain:}

Antiq17, “Perputaran Kas dalam pandangan Islam” https://antiq17.wordpress.com diakses, 30 Oktober 2018 pukul 09.00 Wib.

OliviaMadaRolos,http://reforsitory.usu.ac.id/bitstream/12345678/22388/5/chapter \%201.pdf, diakses pada 16 februari 2018, pukul 12.20 wib. 